\title{
KEPRAKTISAN PERMAINAN ZUPER ABASE BERBASIS ANDROID SEBAGAI MEDIA PEMBELAJARAN ASAM BASA
}

\author{
PRACTICALLY OF ZUPER ABASE GAME BASED ON ANDROID \\ AS AN ACID BASES LEARNING MEDIA
}

\author{
Anggie Bagoes Kurniawan dan *Rusly Hidayah \\ Jurusan Kimia FMIPA Universitas Negeri Surabaya \\ e-mail: ruslyhidayah@unesa.ac.id
}

\begin{abstract}
Abstrak
Salah satu keterampilan abad-21 adalah information media and technology skills. Dalam penerapan kurikulum 2013 ini mengacu pada Permendikbud nomor 22 tahun 2016 tentang standar proses pendidikan dasar dan menengah. Salah satu prinsipnya adalah menggunakan teknologi informasi dan komunikasi untuk meningkatkan efisiensi serta efektivitas pembelajaran. Media pembelajaran berbasis android merupakan salah satu penerapan gaya belajar abad ke-21. Implementasi mobile phone di sekolah dapat menguntungkan sebab perangkat tersebut telah dikenal secara umum oleh peserta didik. Permainan terdiri dari sekumpulan peraturan yang membangun situasi bersaing dari dua hingga beberapa orang maupun kelompok dengan memilih strategi yang dibangun untuk memaksimalkan kemenangan. Pembelajaran menggunakan permainan pasti memiliki manfaat juga. Kepraktisan suatu media memililiki kualitas kepraktisan yang tinggi jika pengguna mempertimbangkan media tersebut dapat digunakan dan realitanya mudah untuk menggunakannya. Penelitian ini menggunakan model R\&D (Research and Development) Borg dan Gall hanya sampai tahap uji coba awal (preliminary field testing. Sasaran penelitian ini adalah peserta didik SMA Negeri 3 Sidoarjo sebanyak 33 orang dengan jenjang kelas XI MIPA. Media permainan zuper abase dapat dikatakan praktis yang ditunjukkan dengan perolehan skor respon peserta didik yang telah menggunakan media permainan yakni sebesar 78,3670\%.
\end{abstract}

Kata kunci: kepraktisan, permainan zuper abase, android, respon peserta didik.

\begin{abstract}
One of the 21st century skills is information media and technology skills. In applying the 2013 curriculum, it refers to Permendikbud number 22 of 2016 concerning basic and secondary education process standards. One principle is to use information and communication technology to improve the efficiency and effectiveness of learning. Android-based learning media is one of the applications of 21 st century learning styles. The implementation of mobile phones in schools can be beneficial because these devices are generally known by students. The game consists of a set of rules that build a competitive situation from two to several people or groups by choosing strategies that are built to maximize victory. Learning to use the game certainly has benefits too. The practicality of a media has a high quality of practicality if the user considers the media to be used and in reality it is easy to use $i t$. This research utilixes the development model by Borg and Gall until preliminary field testing. The targets of this research were 33 students of SMA Negeri 3 Sidoarjo with MIPA XI grade. Zuper abase game media can be said to be practical as indicated by the acquisition of response scores of students who have used the game media that is equal to $78.3670 \%$.
\end{abstract}

Key words: practically, zuper abase game, android, response of students.

\section{PENDAHULUAN}

Dewasa ini topik yang sering diperbincangkan adalah keterampilan abad ke-21 yang memiliki tanggapan berbeda-beda. Trilling dan Fadel mengungkapkan ada 3 keterampilan abad ke-21 yakni life and career skills, learning and innovation skills, dan information media and technology skills [1]. Ketiga keterampilan ini yang 
dijadikan pemerintah sebagai kerangka kerja pembelajaran pada abad 21.

Seiring berjalannya waktu, pendidikan terus mengalami transformasi yang lebih baik. Bukti dilakukannya transformasi ini adalah perubahan kurikulum menjadi kurikulum 2013 edisi revisi tahun 2018. Dalam penerapannya mengacu pada Permendikbud nomor 22 tahun 2016 tentang standar proses pendidikan dasar dan menengah. Salah satu prinsip yakni menggunakan teknologi informasi dan komunikasi untuk meningkatkan efisiensi serta keefektifan pembelajaran.

Peranan guru dalam pembelajaran berbasis teknologi sangatlah penting yakni menyadarkan peserta didik agar memanfaatkan media komunikasi dan teknologi dalam pembelajaran. Dalam pembelajran berbasis teknologi perlu ditunjang dengan guru yang sudah berpengalaman serta mampu dalam bidang teknologi informasi dan komunikasi. Dengan pembelajaran berbasis teknologi diharapkan dapat membantu proses kegiatan belajar mengajar menjadi lebih menarik, menyenangkan serta mudah digunakan oleh pendidik dan peserta didik.

Dalam kurikulum 2013 mata pelajaran kimia termasuk dalam kelompok peminatan C. Tujuan mata pelajaran peminatan kelompok $\mathrm{C}$ adalah untuk mengembangkan sikap, pengetahuan dan kompetensi keterampilan peserta didik sesuai minat, bakat dan atau kemampuan akademik dalam sekelompok mata pelajaran keilmuan.

Sesuai dengan kurikulum, peserta didik kelas XI dituntut untuk memahami berbagai jenis dan sifat larutan jika terjadi reaksi dengan zat lain sehingga mampu mengamati peristiwa yang terjadi dan menerapkannya dalam kehidupan sehari-hari [2]. Salah stau konsep penting dalam kimia adalah materi asam basa. Konsep ini meliputi teori-teori asam dan basa, kekuatan asam dan basa, pengukuran perhitungan $\mathrm{pH}$, reaksireaksi asam basa.

Istilah kata "asam" berasal dari bahasa Latin "acidus" yang berarti masam. Asam adalah zat atau senyawa yang menyebabkan rasa masam pada berbagai materi. Basa adalah zat(senyawa) yang dapat beraksi dengan asam, menghasilkan senyawa yang disebut garam [3].
Setiap zat atau senyawa memiliki sifat asam, basa, atau netral. Kita dapat menentukan apakah zat tersebut asam, basa atau netral dengan menggunakan indikator. Indikator dapat berupa indikator universal atau lakmus biru, lakmus merah yang terdapat pada laboratorium, atau juga dapat menggunakan indikator asam basa dengan bahan dari alam, seperti bunga kembang sepatu, bunga bougenvil, bunga mawar, dan sebagainya [4].

Permendikbud No. 65 Tahun 2013 menyatakan bahwa media perlu digunakan dalam pembelajaran. Media dapat digunakan untuk mengarahkan peserta didk dalam memperoleh berbagai pengalaman belajar. Media pembelajran memiliki nilai-nilai praktis seperti konkritisasi konsep yang abstrak, membawa pesan dari objek yang berbahaya serta sukar bahkan tidak mungkin dibawa dalam lingkungan belajar, menampilkan objek yang tidak dapat diamati oleh mata telajang, menampilan objek yang terlalu besar, mengamati gerakan yang terlalu cepat, memungkinkan peserta didik berinteraksi langsung dengan lingkungan, memungkinkan pengamatan dan persepsi yang seragam, membangkitkan motivasi peserta didik, memberikan kesan perhatian individu bagi anggota kelompok belajar, menyajjikan informasi belajar secara konsisten dan dapat diulang atau disimpan menurut kebutuhan [5].

Chuang mengungkapkan bahwa penggunaan media pembelajaran berbasis android merupakan salah satu penerapan gaya belajar abad ke-21. Penggunakan media pembelajaran sejenis ini memiliki potensi untuk membantu meningkatkan performa akademik peserta didik berupa hasil belajar pada ranah kognitif [6].

Menurut data yang dihimpun dari StatCounter hingga bulan September tahun 2019, penggunaan mobile phone berbasis android mencapai angka 51,96\% [7]. Ini membuktikan bahwa mobile phone berbasis android telah dikenal oleh masyarakat Indonesia. Implementasi mobile phone di sekolah dapat menguntungkan sebab perangkat tersebut telah dikenal secara umum oleh peserta didik dan merupakan alat yang 
banyak digunakan dalam pembelajaran masa depan [8].

Belajar akan efektif jika dilakukan dengan suasana yang menyenangkan (fun and enjoy) [9]. Pembelajaran dikatakan menyenangkan apabila suasana pembelajaran dapat meningkatkan gairah belajar, menggembirakan hati, membuat peserta didik nyaman di tempat belajar sehingga pusat perhatian peserta didik secara penuh kepada belajar, artinya waktu curah perhatiannya (time on ask) tinggi [10].

Permainan terdiri dari sekumpulan peraturan yang membangun situasi untuk bersaing dari dua hingga beberapa orang maupun kelompok dengan memilih strategi yang dibangun untuk mendapatkan kemenangan. Permainan edukatif merupakan salah satu bentuk permainan yang dapat mengembangkan keterampilan, minat pemikiran serta perasaannya [11]. Segala hal yang dilakukan dan diciptakan oleh guru dalam kegiatan belajar mengajar dikelas pasti memilki tujuan yang baik serta memiliki manfaat yang baik juga bagi yang merasakan. Pembelajaran menggunakan permainan pasti memiliki manfaat juga. Dvořáková mengemukakan bawa permainan dalam pembelajaran memiliki manfaat yakni dengan permainan peserta didik menjadi termotivasi untuk bekerja sama, permainan mengembangkan pemikiran yang kreatif, kemampuan yang berkombinasi, kemampuan mencari strategi baru, menciptakan aktivitas spontan tanpa stress, dan mendapat pengetahuan baru [12].

Permainan Zuper Abase ini merupakan media pembelajaran yang dioperasikan menggunakan sistem operasi android. Media permainan ini adalah media pembelajaran kimia berbasis android yang bergenre petualangan (advanture). Dimana terdapat tokoh utama seorang peserta didik yang bernama Abase yang diminta untuk membersihkan wastafel yang berkerak di laboratorium oleh Profesornya. Profesor ini menginstruksikan untuk menghubungkan dengan materi asam basa yang sudah dia peroleh. Sehingga dia mendapatkan $\mathrm{HCl}$ sebagai bahan pembersih.

Kepraktisan suatu media memililiki kualitas kepraktisan yang tinggi jika pengguna mempertimbangkan media tersebut dapat digunakan dan realitanya guru dan peserta didik mudah untuk menggunakannya. Media permainan dikatakan praktis apabila media permainan mudah digunakan, dapat menarik rasa ingin tahu pengguna, memiliki materi yang jelas, serta dapat meningkatkan motivasi peserta didik [13].

\section{METODE}

Data yang didapatkan dari penelitian ini merupakan data jenis kuantitatif yang merupakan data pokok penelitian yang berupa penilaian tentang media permainan oleh peserta didik.

Sampel penelitian ini adalah peserta didik SMA Negeri 3 Sidoarjo sebanyak 33 orang dengan jenjang kelas XI MIPA. Jumlah 33 peserta didik termasuk dalam sampel non-probability dan sampel purposive karena sekolah sudah menetapkan kelas yang digunakan untuk mengambil data.

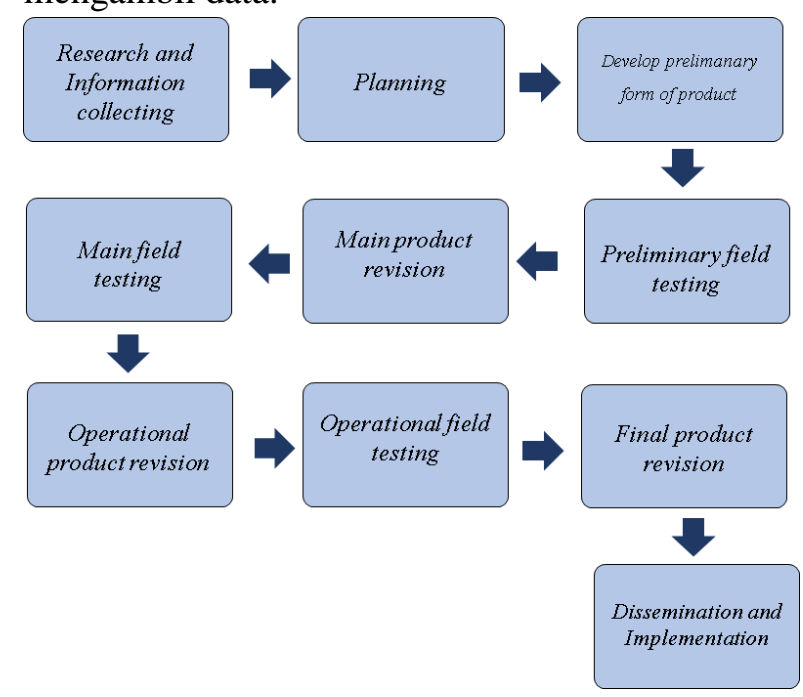

Gambar 1. Langkah-Langkah Penggunaan Metode Research and Development (R\&D).

Penelitian ini merupakan penelitian pengembangan dengan mengadaptasi model pengembangan milik Borg dan Gall yang terdiri atas 10 tahapan [14]. Namun untuk penelitian ini hanya dilakukan sampai tahapan uji coba awal (preliminary field testing).

Metode yang digunakan dalam penelitian ini adalah metode angket. Metode angket digunakan untuk memperoleh nilai kepraktisan dengan berupa angket respon peserta didik setelah menggunakan media permainan ini [15]. 
Data hasil respon peserta didik terhadap media permainan dianalisis dengan menghitung kepraktisan dengan menggunakan ketentuan pernyataan sebagai berikut.

Tabel 1. Ketentuan Pernyataan Angket Respon

\begin{tabular}{cc}
\hline Skor & Kriteria \\
\hline 0 & Sangat Tidak Setuju \\
1 & Tidak Setuju \\
2 & Setuju \\
3 & Sangat Setuju \\
\hline
\end{tabular}

Hasil skor akhir yang diperoleh adalah skor rata-rata. Skor rata-rata tersebut dikonversikan dalam bentuk persen untuk menentukan tingkat keterbatasan peserta didik terhadap media permainan. Analisis data untuk mengartikan respon peserta didik sebagai berikut. Persentase tiap aspek $(\%)=\frac{\text { jumla } h \text { skor rata }- \text { rata tiap aspek }}{\text { skala ideal }} \times 100 \%$

Dengan skor ideal sebagai berikut.

Skor ideal $=$ skor terting gi $\times$ jumlah responden

Untuk persentase kepraktisan berdasarkan lembar respon peserta didik dihitung menggunakan rumus sebagai berikut.

Persentase kepraktisan $(\%)=\frac{\text { jumla } h \text { persentase tiap aspek }}{\text { jumla } h \text { aspek }}$

Hasil analisis ini digunakan untuk menentukan kepraktisan dari media permainan zuper abase dengan menggunakan interpretasi skor pada tabel 2 .

Tabel 2. Interpretasi Kepraktisan Media

\begin{tabular}{cc}
\hline Persentase (\%) & Kriteria \\
\hline $0-20$ & Tidak Praktis \\
$21-40$ & Kurang Praktis \\
$41-60$ & Cukup Praktis \\
$61-80$ & Praktis \\
$81-100$ & Sangat Praktis \\
\hline
\end{tabular}

Media Permainan dikatakan praktis apabila memperoleh persentase kepraktisan berada pada latagori praktis hingga sangat praktis atau mencapai skor $\geq 61 \%$.

\section{HASIL DAN PEMBAHASAN}

\section{Research and Information Collecting}

Tujuan dari tahapan ini adalah untuk mendapatkan informasi yang dibutuhkan oleh peserta didik dan guru. Selain itu juga untuk mempersiapkan perlengkapan serta sumber daya manusia yang dibutuhkan untuk mengembangkan media permainan ini. Data yang didapatkan adalah pembelajaran kimia tidak menarik atau dikatakan membosankan karena bahan ajar yang didapatkan oleh peserta didik berupa soal-soal latihan saja. $\mathrm{KD}$ dan indikator pembelajaran materi pokok asam basa berdasarkan silabus kurikulum 2013.

a.Kompetensi Dasar (KD)

3.10 Memahami konsep asam dan basa serta kekuatannya dan kesetimbangan pengionannya dalam larutan.

b.Indikator Pembelajaran (IP)

3.10.1 Menjelaskan perkembangan teori asam dan basa.

3.10.2Menjelaskan kelebihan dan kekurangan perkembangan teori asam dan basa.

3.10.3 Mengklasifikasikan larutan asam dan larutan basa.

\section{Planning}

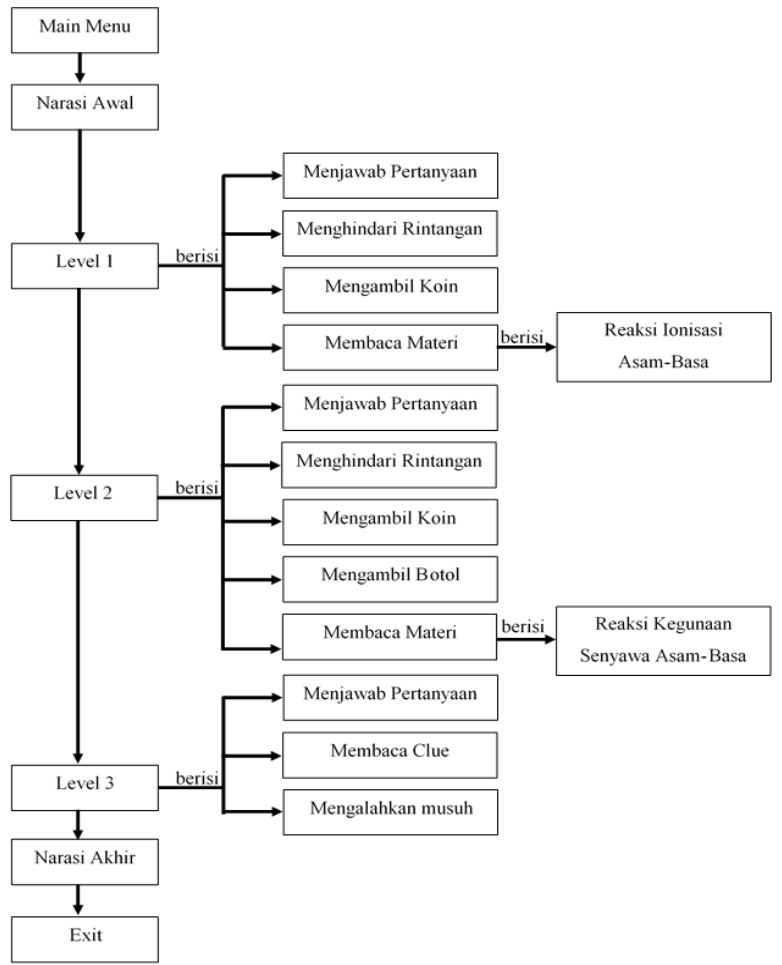

Gambar 2. Garis Besar Isi Media Permainan Zuper Abase.

Tahapan kedua dalam proses pengembangan menurut Borg dan Gall yakni planning (perencanaan). Membuat suatu perencanaan adalah hal yang sangat penting dan dibutuhkan agar proses menjadi efektif dan efisien. Dari data yang didapatkan pengembangan media pembelajaran berbasis android dirasa sesuai. Secara garis besar, isi dari media 
permainan ini tertuang pada gambar 2 . Pemanfaatan media pembelajaran sangat erat dengan peningkatan kualitas pembelajaran. Dengan memanfaatkan media diharapkan menciptakan pengalaman belajar yang lebih bermakna, memfalisitasi proses interaksi antara pendidik dengan peserta didik, sesama peserta didik, serta memperkaya pengalaman belajar.

\section{Develop Preliminary Product}

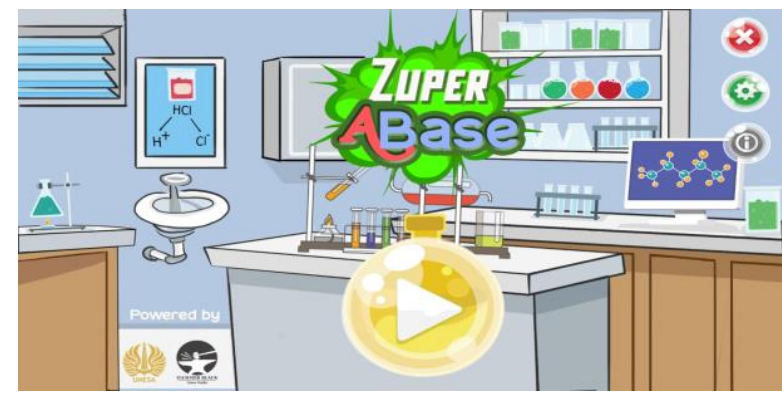

Gambar 3. Tampilan Permainan Zuper Abase

Tahap ketiga ini terdiri dari mengembangkan desain produk, pembuatan instrumen yang mendukung penelitian, dan menyusun rencana pembelajaran di kelas. Pada proses pembuatan gambar latar belakang, tokoh animasi menggunakan adobe photoshop CS 5, sedangkan untuk membut perangkat lunak media permainan menggunakan Unity versi 2019.2.6f1. Selain media permainan yang dikembangkan, perangkat instrumen yang juga dikembangkan adalah lembar angket peserta didik.Hasil dari permainan yang dikembangkan dapat dilihat pada gambar tiga.

\section{Preliminary Testing}

Uji coba ini dilaksanakan di SMA Negeri 3 Sidoarjo dengan responden sebanyak 33 peserta didik kelas XI MIPA 2. Responden ini termasuk dalam sampel non-probability dan sampel purposive karena sekolah sudah menetapkan kelas yang digunakan untuk dilakukan uji coba.

Kepraktisan dari permainan ini diketahui dari peserta didik yang telah menggunakan media permainan zuper abase berbasis android dengan mengisi lembar angket respon pengguna. Angket respon tersebut menggunakan skala likert seperti yang tersaji pada tabel 1. Hasil yang didapatkan dari lembar angket respon pengguna tertuang dalam tabel 3.

Tabel 3. Hasil Angket Respon Pengguna

\begin{tabular}{|c|c|c|c|c|c|c|c|c|c|}
\hline \multirow[t]{2}{*}{ No. } & \multirow[t]{2}{*}{ Tujuan } & \multirow{2}{*}{\multicolumn{2}{|c|}{ Aspek yang diamati }} & \multicolumn{4}{|c|}{ Frekuensi } & \multirow[t]{2}{*}{ Skor } & \multirow{2}{*}{$\begin{array}{c}\text { Respon } \\
(\%)\end{array}$} \\
\hline & & & & SS & $\mathbf{S}$ & TS & STS & & \\
\hline \multirow[t]{3}{*}{1} & $\begin{array}{l}\text { Mengetahui } \\
\text { media } \\
\text { permainan } \\
\text { mudah }\end{array}$ & a. & $\begin{array}{l}\text { Saya mampu } \\
\text { memainkan permainan } \\
\text { Zuper Abase dengan } \\
\text { lancar }\end{array}$ & 14 & 15 & 4 & 0 & 25,3333 & 76,7677 \\
\hline & digunakan & b. & $\begin{array}{l}\text { Saya memahami } \\
\text { aturan permainan pada } \\
\text { Zuper Abase }\end{array}$ & 16 & 15 & 2 & 0 & 26,6667 & 80,8081 \\
\hline & & c. & $\begin{array}{l}\text { Permainan Zuper } \\
\text { Abase memiliki bahasa } \\
\text { yang mudah dipahami }\end{array}$ & 16 & 15 & 2 & 0 & 26,6667 & 80,8081 \\
\hline \multirow[t]{3}{*}{2} & $\begin{array}{l}\text { Mengetahui } \\
\text { media } \\
\text { permainan } \\
\text { dapat menarik } \\
\text { rasa ingin tahu } \\
\text { peserta didik }\end{array}$ & a. & $\begin{array}{l}\text { Saya tidak merasa } \\
\text { bosan jika } \\
\text { pembelajaran } \\
\text { menggunakan media } \\
\text { permainan Zuper } \\
\text { Abase }\end{array}$ & 16 & 17 & 0 & 0 & 27,3333 & 82,8283 \\
\hline & & b. & $\begin{array}{l}\text { Media permainan } \\
\text { Zuper Abase } \\
\text { menyenangkan untuk } \\
\text { dimainkan }\end{array}$ & 18 & 14 & 1 & 0 & 27,6667 & 83,8384 \\
\hline & & c. & $\begin{array}{l}\text { Media permainan } \\
\text { Zuper Abase pada }\end{array}$ & 18 & 15 & 0 & 0 & 28,0000 & 84,8485 \\
\hline
\end{tabular}




\begin{tabular}{|c|c|c|c|c|c|c|c|c|c|}
\hline \multirow[t]{2}{*}{ No. } & \multirow[t]{2}{*}{ Tujuan } & \multirow{2}{*}{\multicolumn{2}{|c|}{ Aspek yang diamati }} & \multicolumn{4}{|c|}{ Frekuensi } & \multirow[t]{2}{*}{ Skor } & \multirow{2}{*}{$\begin{array}{c}\text { Respon } \\
(\%)\end{array}$} \\
\hline & & & & SS & $\mathbf{S}$ & TS & STS & & \\
\hline \multirow{4}{*}{3} & \multirow{4}{*}{$\begin{array}{l}\text { Mengetahui } \\
\text { kejelasan materi } \\
\text { yang terdapat } \\
\text { dalam media } \\
\text { permainan }\end{array}$} & & $\begin{array}{l}\text { materi asam basa } \\
\text { menarik untuk } \\
\text { dimainkan }\end{array}$ & 18 & 15 & 0 & 0 & 28,0000 & 84,8485 \\
\hline & & $\mathrm{d}$. & $\begin{array}{l}\text { Saya ingin memainkan } \\
\text { permainan Zuper } \\
\text { Abase terus menerus }\end{array}$ & 8 & 10 & 14 & 1 & 19,3333 & 58,5859 \\
\hline & & a. & $\begin{array}{l}\text { Media permainan } \\
\text { Zuper Abase pada } \\
\text { materi asam basa } \\
\text { terdapat materi penting } \\
\text { yang harus saya } \\
\text { pahami }\end{array}$ & 17 & 16 & 0 & 0 & 27,6667 & 83,8384 \\
\hline & & b. & $\begin{array}{l}\text { Media permainan } \\
\text { Zuper Abase pada } \\
\text { materi asam basa } \\
\text { mempermudah saya } \\
\text { memahami materi } \\
\text { asam basa }\end{array}$ & 15 & 18 & 0 & 0 & 27,0000 & 81,8182 \\
\hline \multirow[t]{3}{*}{4} & \multirow{3}{*}{$\begin{array}{l}\text { Mengetahui } \\
\text { media } \\
\text { permainan } \\
\text { dapat } \\
\text { meningkatkan } \\
\text { motivasi belajar } \\
\text { peserta didik }\end{array}$} & a. & $\begin{array}{l}\text { Saya belajar sungguh- } \\
\text { sungguh melalui media } \\
\text { permainan Zuper } \\
\text { Abase }\end{array}$ & 7 & 18 & 8 & 0 & 21,6667 & 65,6566 \\
\hline & & b. & $\begin{array}{l}\text { Media permainan } \\
\text { Zuper Abase pada } \\
\text { materi asam basa } \\
\text { terdapat materi penting } \\
\text { yang harus saya } \\
\text { pahami }\end{array}$ & 16 & 17 & 0 & 0 & 27,3333 & 82,8283 \\
\hline & & c. & $\begin{array}{l}\text { Permainan Zuper } \\
\text { Abase memotivasi } \\
\text { saya untuk semangat } \\
\text { belajar }\end{array}$ & 14 & 16 & 3 & 0 & 25,6667 & 77,7778 \\
\hline
\end{tabular}

Dari data tersebut dapat diungkapkan bahwa peserta didik setuju bahwa permainan zuper abase mudah digunakan yang ditunjukkan dengan 3 indikator yakni mampu memainkan dengan lancar, memahami aturan main dan bahasa yang mudah dipahami yang masing-masing memperoleh respon $76,7677 \%, 80,8081 \%$ dan $80,8081 \%$.

Selain itu peserta didik setuju media permainan dapat menarik rasa ingin tahu yang dicerminkan dengan perolehan persentase $82,8283 \%$ untuk indikator tidak merasa bosan jika Terapat tiga indikator dalam tujuan ini yakni peserta didik belajar dengan sungguh-sungguh menggunakan media ini, media memiliki materi yang penting dan memotivasi untuk semangat pembelajaran menggunakan media permainan ini, $82,8384 \%$ media permainan zuper abase menyenangkan, $84,8485 \%$ menarik untuk dimainkan dan 58,5859\% ingin memainkan terus menerus. Untuk tujuan yang ketiga peserta didik merasa jelas untuk materi yang terdapat dalam media permainan. Tujuan ketiga ini memiliki dua indikator yakni terdapat materi penting yang harus dipahami dan mempermudah memahami materi masing-masing memperoleh $83,8384 \%$ dan $81,8182 \%$. Tujuan yang terakhir meningkatkan motivasi peserta didik dalam belajar. belajar masing-masing mendapat 65,6566\%, $82,8283 \%$ dan $77,7778 \%$.

Dari kumpulan data yang didapatkan kepraktisan media permainan zuper abase 
memperoleh rata-rata respon sebesar 78,3670\%. Skor tersebut termasuk dalam katagori praktis.

\section{SIMPULAN}

Berdasarkan pembahasan di atas maka dapat ditarik kesimpulan bahwa media permainan zuper abase dikatakan praktis yang ditunjukkan dengan perolehan skor respon peserta didik yang telah menggunakan media permainan yakni sebesar 78,3670\%.

\section{DAFTAR PUSTAKA}

1. Trilling, \& Fadel. 2009. 21st Century Skills: Learning for Life in Our Times. USA: Jossey Bass.

2. Suyanti, R. D. 2010. Strategi Pembelajaran Kimia. Yogyakarta: Graha Ilmu.

3. Petrucci, R. H., Harwood, W. S., \& Herring, F. G. 2011. Kimia Dasar Prinsip-Prinsip dan Aplikasi Modern. Jakarta: Erlangga.

4. Ripani. 2009. Pengantar Kimia Asam-Basa. Jakarta: Erlangga.

5. Nuryanto, A. 2016. BAB III BAHASAN MEDIA PENGAJARAN. Retrieved September 15, 2019, from BAB III BAHASAN MEDIA PENGAJARAN:

http://staffnew.uny.ac.id/upload/132296045/1 ainlain/media+pembelajaran.pdf

6. Chuang, T. Y., \& Chen, W. F. 2007. Effect of Digital Games on Children's Cognitive Achievement. Journal of Multimedia, 27-30.

7. Statcounter, 2019. Statcounter. [Online] Available at: https://gs.statcounter.com/osversion-marketshare/windows/desktop/indonesia\#monthly201809-201909-bar
8. Mohammad, M., Maringe, F., \& Wollard, J. 2012. Mobile Learning in Malaysian Schools: Opportunities and Challenges of Introducing Teaching Through Mobile Phones. International Journal For $e$ Learning Security (IJeLS), 133-137.

9. Dryden, G., \& Vos, J. 2002. The learning revolution : to change the way the world learns. Stafford, United Kingdom: Network Educational Press.

10. Suyono, \& Hariyanto. 2012. Belajar dan Pembelajaran: Teori dan Konsep Dasar. Bandung: Remaja Rosda Karya.

11. Mulyati, Y. 2005. Permainan edukatif pada anak. Yogyakarta: Pustaka Pelajar.

12. Dvořáková, 2007. Spiele im Deutchunterrich. Diakses pada 9 September 2019, dari https://is.muni.cz/th/79404/pedf_m/diplom.pr ace.pdf.

13. Akker, J. V., Bannan, B., Kelly, A. E., Nieveen, N., \& Plomp, T. (2010). An Introduction to Educational Design Researc. Enschede: SLO.

14. Borg, W. R., \& Gall, M. D. 2003. Educational Research: An Introduction Seventh Edition. Boston: Pearson Education Inc.

15. Hidayah, R., \& Destari, T. Y. 2019. The Practicality of Scrap-mod as a Learning Media on Molecular Geometry. (pp. 222226). Surabaya: Atlantis Press.

16. Sugiyono. 2016. Metode Penelitian Kuantitatif Kualitatif dan $R \& D$. Bandung: Alfabeta.

17. Riduwan. 2015. Skala Pengukuran VariabelVariabel Penelitian. Bandung: Alfabeta. 